\title{
THE ENDEMIC CLADOPHORALES (ULVOPHYCEAE) OF ANCIENT LAKE BAIKAL REPRESENT A MONOPHYLETIC GROUP OF VERY CLOSELY RELATED BUT MORPHOLOGICALLY DIVERSE SPECIES ${ }^{1}$
}

\author{
Christian Boedeker ${ }^{2}$ (iD \\ School of Biological Sciences, Victoria University of Wellington, PO Box 600, Wellington 6140, New Zealand \\ Frederik Leliaert (iD) \\ Botanic Garden Meise, Nieuwelaan 38, 1860, MeiseBelgium \\ Phycology Research Group, Biology Department, Ghent University, Krijgslaan 281 S8, 9000 Ghent, Belgium \\ Oleg A. Timoshkin \\ Limnological Institute of the Russian Academy of Sciences, Ulan-Batorskaya 3, 664033 Irkutsk, Russia \\ Vasily S. Vishnyakov \\ Papanin Institute for Biology of Inland Waters of the Russian Academy of Sciences, 152742 Borok, Yaroslavl, Russia \\ Sergio Díaz-Martínez (D), and Giuseppe C. Zuccarello (D) \\ School of Biological Sciences, Victoria University of Wellington, PO Box 600, Wellington 6140, New Zealand
}

Lake Baikal, the oldest lake in the world, is home to spectacular biodiversity and extraordinary levels of endemism. While many of the animal species flocks from Lake Baikal are famous examples of evolutionary radiations, the lake also includes a wide diversity of endemic algae that are not well investigated with regards to molecular-biological taxonomy and phylogeny. The endemic taxa of the green algal order Cladophorales show a range of divergent morphologies that led to their classification in four genera in two families. We sequenced partial large- and small-subunit rDNA as well as the internal transcribed spacer region of 14 of the 16 described endemic taxa to clarify their phylogenetic relationships. One endemic morphospecies, Cladophora kusnetzowii, was shown to be conspecific with the widespread Aegagropila linnaei. All other endemic morphospecies formed a monophyletic group nested within the genus Rhizoclonium (Cladophoraceae), a very surprising result, in stark contrast to their morphological affinities. The Baikal clade represents a species flock of closely related taxa with very low genetic differentiation. Some of the morphospecies were congruent with lineages recovered in the phylogenies, but due to the low phylogenetic signal in the rDNA sequences the relationships within the Baikal clade were not all well resolved. The Baikal clade appears to represent a recent radiation, based

\footnotetext{
${ }^{1}$ Received 8 March 2018. Accepted 6 July 2018. First Published Online 4 August 2018. Published Online 12 September 2018, Wiley Online Library (wileyonlinelibrary.com).

${ }^{2}$ Author for correspondence: e-mail christian.boedeker@vuw.ac.nz.

Editorial Responsibility: H. Verbruggen (Associate Editor)
}

on the low molecular divergence within the group, and it is hypothesized that the large morphological variation results from diversification in sympatry from a common ancestor in Lake Baikal.

Key index words: green algae; molecular phylogenetics; rDNA; recent radiation; species flock; sympatry

Abbreviations: BI, Bayesian Inference; ML, maximum likelihood

Ancient lakes are lakes that are more than one million years old, and $\sim 20$ such lakes exist around the world (e.g., Martens 1997, Rossiter and Kawanabe 2000). The age of those lakes makes them "natural laboratories" for studies of diversification, especially (sympatric) speciation and radiation processes, and they are typically characterized by large numbers of closely related endemic species that evolved in parapatry or sympatry and which may represent cases of adaptive radiations (Martens 1997, Sherbakov 1999, Herder et al. 2008, Genner and Turner 2011). These radiations result in socalled "species flocks," which are monophyletic, species-rich groups of endemic taxa (Greenwood 1984, Schön and Martens 2004). Species flocks of sponges, ciliophorans, turbellarians, nematodes, annelids, rotifera, polychaetes, bivalves, gastropods, ostracods, isopods, cladocerans, copepods, amphipods, crabs, chironomides, caddis flies, water mites, sculpins, and cichlids, have been reported from ancient lakes (Kozhov 1963, Mazepova 1990, Sherbakov 1999, Timoshkin 2001-2011, Hausdorf et al. 2003, Kontula et al. 2003, Schön and Martens 2004, 
2012, Semernoy 2004, Seehausen 2006, Albrecht and Wilke 2008, Glaubrecht and von Rintelen 2008, Wiens et al. 2009, Shirokaya et al. 2017). It is striking that to date species flocks in ancient lakes have been reported almost exclusively for animal taxa and for no algal or plant group except diatoms (Mann 1999, Flower 2005, Edlund and Soninkhishig 2009, Kulikovskiy et al. 2012).

Lake Baikal, situated in southeast Siberia, Russia, is the world's oldest lake (formed 28-30 mya; Mats 1993) and has the largest volume. The lake is characterized by exceptionally high biodiversity, more than half of the $\sim 2600$ species are endemics, and up to $64 \%-80 \%$ endemics in animals (Timoshkin 1999, 2001-2011, Timoshkin et al. 2004). Lake Baikal has very unique ecological conditions as it is cold all year (rarely above $4^{\circ} \mathrm{C}$, but summer surface temperatures can be considerably higher in some of the few shallower parts) and covered by ice in winter and spring. The water is ultraoligotrophic with low levels of ions and dissolved organic carbon (Kozhova and Izmest'eva 1998).

Lake Baikal has shifted from a subtropical to a temperate climate during the past 5 million years (Sherstyankin and Kuimova 2006), which led to shifts in community composition and diversification in selected groups of organisms (Sherbakov 1999). Several rapid evolutionary radiations have been linked to historical events of drastic changes in environmental conditions providing settings of ecological opportunity with newly available niches (Yoder et al. 2010, Genner and Turner 2011, Hou et al. 2011, Schön and Martens 2012). Diversification of several animal groups (e.g., ostracods, gastropods, sculpins, and some oligochaetes) date back to the recent cooling of Lake Baikal during the Pleistocene ( 2 mya; Sherbakov 1999, Hausdorf et al. 2003, Kontula et al. 2003, Yokoyama and Goto 2005, Kaygorodova et al. 2007, Schön and Martens 2012, Stelbrink et al. 2015, Karanovic and Sitnikova 2017).

Algae in Lake Baikal are highly diverse, and a large number of endemic species has been described (e.g., Meyer 1925, 1926, Izhboldina 2007, Kulikovskiy et al. 2012), but their evolutionary history has not yet been studied in detail. One group that is represented by a considerable number of endemics is the green algal order Cladophorales, for which 16 endemic taxa (14 species plus 2 varieties) have been described from Lake Baikal and are currently recognized (Meyer 1922, 1926, 1927, 1930a,b, Skabichevsky 1931, 1936, 1965, 1968, 1969, 1970, 1976, Meyer and Skabichevsky 1965, Izhboldina 2007, see Table S1 in the Supporting Information). The Cladophorales include more than 200 species that essentially have uniseriate filamentous thalli with multinucleate cells. Five lineages at the family level are currently recognized: the monotypic marine Okellyaceae, the marine Pseudocladophoraceae with only two species, the mainly brackish and freshwater Pithophoraceae, the strictly marine and morphologically more complex "Siphonocladus clade", and the Cladophoraceae with some freshwater but mostly marine representatives (Hanyuda et al. 2002, Leliaert et al. 2003, 2007, 2009a, Boedeker et al. 2012, 2016). The simple thallus architecture and scarcity of morphological characters, convergent and parallel evolution as well as phenotypic plasticity has led to persistent classification difficulties at all taxonomic levels. Branched Cladophora-like morphologies are found in four of the five families of the Cladophorales, and most genera of the order were found to be polyphyletic when molecular phylogenetic methods were used. The application of DNA sequence data has led to major taxonomic revisions in this order. The latest phylogenies indicate that freshwater environments have been invaded independently at least three times within the Cladophorales (Pithophoraceae, Cladophora, and Rhizoclonium; Boedeker et al. 2016).

Based on morphology, the endemic Cladophorales from Lake Baikal are currently classified in four genera: Chaetomorpha, Chaetocladiella, Cladophora, and Gemmiphora (Table S1). Fourteen species have been described in these genera, namely, Chaetomorpha baicalensis (Fig. 1A), Chaetomorpha moniliformis (Fig. 1B), Chaetomorpha curta (Fig. 1C), Chaetocladiella pumila (Fig. 1D), Chaetocladiella litoralis, Chaetocladiella microscopica, Cladophora compacta (Fig. 1, E-G), Cladophora floccosa (Fig. 1, H-J), Cladophora kusnetzowii, Cladophora meyeri Skabichevsky (Fig. 1, K and L), Cladophora pulvinata (Fig. 1N), Cladophora kursanovii (Fig. 1, O-Q), Cladophora globulus (Fig. 1R), and Gemmiphora compacta (Fig. 1, S and $\mathrm{T})$. Several species were previously classified as Aegagropila but have since been transferred to Cladophora (Skabichevsky 1976, Izhboldina 2007). The taxonomic affinities of the Baikal taxa have been subject to speculation, but no molecular data exist to date. Generally, it is thought that these taxa belong to the family Pithophoraceae, with most of the taxa assumed to be closely related to Aegagropila, and the genus Chaetocladiella assumed to be closely related to Arnoldiella (Bourrelly 1966, Skabichevsky 1976, Boedeker et al. 2012). The unbranched Chaetomorpha and the branched Cladophora are cosmopolitan genera that are mainly distributed in marine environments. Chaetomorpha has actually no confirmed freshwater representatives outside Lake Baikal (see Boedeker et al. 2016, Škaloud et al. 2018). The genera Chaetocladiella and Gemmiphora are endemic to Lake Baikal and have unique morphologies. While having a simple basic structure, the endemic Cladophorales from Lake Baikal display an astounding range of morphological diversity. The morphological range displayed by these taxa is as large as in the entire order Cladophorales (Figs. 1 and 2), ranging from: hemispherical cushions consisting of intertwined filaments (Figs. 1, EG; 2A); creeping branched filaments forming crusts (Figs. 1, O-Q; 2B); upright tufts (Figs. 1, H-J; 2C); 
turfs on small pebbles (Figs. 1, K and L; 2D); stiff unbranched filaments that are either attached (Figs. 1B and 2E) or unattached (Fig. 2F); entangled woolly masses consisting of soft unbranched filaments (Figs. 1A and 2G); to upright thalli that are only basally branched (Figs. $1 \mathrm{D}$ and $2 \mathrm{H}$ ). In many ways, these algae are unusual as they are slow growing and perennial, and spend a large part of the year in low light under the lake ice cover. Vegetative reproduction is considered to play an important role in most if not all taxa (Izhboldina 2007). The presumed Baikalian endemics Cladophora floccosa and Chaetocladiella miscroscopica (as Chaetomorpha solitaria) have also been reported from the 20-million-year-old Lake Hövsgöl (Khovsgol nuur/Khubsugul) in Mongolia (Zagorenko and Izhboldina 1976, 1983, Kozhova et al. 1994, Rossiter and Kawanabe 2000), which is connected to nearby Lake Baikal via rivers. Lake Baikal is the only place in the world where so many freshwater species of Cladophorales co-occur, which raises the question whether these taxa could represent a species flock as the result of a sympatric evolutionary radiation.

In this study, we aim to investigate species diversity and phylogenetic affinities of the Cladophorales from Lake Baikal based on DNA sequence data.

\section{MATERIALS AND METHODS}

Taxon sampling and morphological identification. Specimens were collected during two boat expeditions in June-July 2011 and in September 2014 from 12 sites around Lake Baikal (Fig. S1 in the Supporting Information) by SCUBA diving. Living specimens were identified morphologically using a bright-field microscope according to the taxonomic treatment of Izhboldina (2007). Vouchers were preserved in ethanol and silica gel and deposited in WELT. Our collections represent 14 of the 16 described endemic taxa, as Chaetocladiella litoralis and Chaetocladiella microscopica were not found.

Molecular markers and phylogenetic analyses. Total genomic DNA was isolated using the Chelex method (Goff and Moon 1993) from 42 specimens of endemic taxa from Lake Baikal; plus four Rhizoclonium specimens from Lake Baikal; and eight specimens of other Cladophora species from Lake Baikal and the Olkha river (a tributary to the Irkut river near Irkutsk, $60 \mathrm{~km}$ west of Lake Baikal) as well as from Lake Davaa in Mongolia (Table S2 in the Supporting Information). In addition, DNA was extracted from 11 samples of Rhizoclonium from various other locations. Molecular phylogenetic analyses were based on nuclear-encoded small-subunit (SSU) and partial large-subunit (LSU) rDNA sequences as well as on the typically more variable internally transcribed spacer regions ITS1 and ITS2 (ITS). The first $\sim 590$ base pairs (bp) of the LSU rDNA were amplified using the universal primers C'1 forward and D2 reverse (Hassouna et al. 1984, Leliaert et al. 2003). About 1,700 bp of the SSU rRNA gene were amplified using the primer pairs SR1-SS11H and SSU897-18SC2 (Leliaert et al. 2007). The whole ITS region was amplified with the primers $9 \mathrm{~F}$ and $7 \mathrm{R}$ (Hayakawa et al. 2012), resulting in $\sim 1,000 \mathrm{bp}$ long fragments. For specimens that showed contamination from epiphytes, a novel and specific ITS forward primer was used (21F: 5'-CTGGTGAAATGTTCGGATTG-3'). For some samples, the ITS1 and ITS2 regions were amplified separately. ITS1 was amplified using the primer pair ITS5ITS2 (White et al. 1990) and ITS2 was amplified using the primer pair ITS3-ITS4 (White et al. 1990).

PCR amplifications were carried out with an initial denaturation step of $94^{\circ} \mathrm{C}$ for $5 \mathrm{~min}$ followed by 30-34 cycles of $1 \mathrm{~min}$ at $94^{\circ} \mathrm{C}, 1 \mathrm{~min}$ at $56^{\circ} \mathrm{C}-57^{\circ} \mathrm{C}$ for the LSU and SSU primers or at $59^{\circ} \mathrm{C}-63^{\circ} \mathrm{C}$ for the primers for the whole ITS region (9F or $21 \mathrm{~F}$ and $7 \mathrm{R}$ ) or at $50^{\circ} \mathrm{C}-54^{\circ} \mathrm{C}$ for the ITS1 and ITS2 primers, and $1 \mathrm{~min}$ at $72^{\circ} \mathrm{C}$, and a final extension step of $5 \mathrm{~min}$ at $72^{\circ} \mathrm{C}$. The reaction volume was $25 \mu \mathrm{L}$ and consisted of $\sim 0.1-0.4 \mu \mathrm{g}$ genomic DNA, $1.25 \mathrm{nmol}$ of each dNTP, 6 pmol of each primer, $1 \times$ reaction buffer, $1-2.5 \mathrm{mM} \mathrm{MgCl}_{2}$, $5 \mu \mathrm{L} 0.25 \% \mathrm{BSA}$, up to $5 \mu \mathrm{L} 5 \mathrm{M}$ betaine, and one unit of Taq polymerase (Bioline, London, UK). The annealing temperature for the ITS primers as well as the amounts of $\mathrm{MgCl}_{2}$ and betaine varied depending on the amplification success of particular specimens. Amplifications were checked for correct size by electrophoresis on $1 \%$ agarose gels. PCR products were purified with ExoSAP-IT ${ }^{\circledR}$ (USB Corporation OH, USA). Cleaned PCR products were commercially sequenced (Macrogen, Seoul, Korea). DNA sequence data generated for this study were deposited at EMBL-ENA (GenBank) under study number PRJEB27736 with the following accession numbers: LS974910-LS974971 (LSU), LS974859-LS974909 (SSU), and LS974972-LS975026, and LS990757-LS990767 (ITS), listed in Table S2.

The LSU, SSU, and ITS sequences were aligned separately with MUSCLE (Edgar 2004) using the default settings and then edited by eye in Se-Al v2.0a11 (Rambaut 2007). A data set of 20 ITS2 sequences of Rhizoclonium specimens from various locations worldwide was assembled to calculate maximum pair-wise differences in comparison with the taxa from Lake Baikal but could not be aligned confidently. Therefore, this set of sequences was automatically aligned in MUSCLE using a gap open score of -0.5 , resulting in many gaps which equals missing data and thus avoiding aligning nonhomologuous sites to obtain a very conservative estimate of sequence divergence.

A preliminary data set with $150 \mathrm{LSU}$ and SSU sequences of the order Cladophorales, consisting of the samples from Lake Baikal and additional sequences downloaded from GenBank

FIG. 1. Morphology of the endemic cladophorales of Lake Baikal. (A) Chaetomorpha baicalensis; (B) Chaetomorpha moniliformis; (C) Chaetomorpha curta; (D) Chaetocladiella pumila; (E-G) Cladophora compacta: (E) falcate branching in upper parts of thallus, (F) terminal sporangia, $(\mathrm{G})$ irregular branching and thick cell walls in lower parts of thallus; (H-J) Cladophora floccosa: $(\mathrm{H})$ two young thalli, (J) older thallus showing holdfast, falcate branching in upper parts, and terminal chain of sporangia; (K, L) Cladophora meyeri: (K) upper part of thallus, showing irregular branching, delayed cell wall formation, and a terminal chain of three sporangia, (L) whole thallus showing irregular branching and thick cell walls; (M, N) Cladophora pulvinata: (M) densely branched apical region of thallus showing various modes of branch insertion and formation of terminal chains of sporangia, $(\mathrm{N})$ apical branch system, showing subterminal branch insertion and change in cell diameter and shape in forming sporangia; $(\mathrm{O}-\mathrm{Q})$ Cladophora kursanovii: $(\mathrm{O})$ part of thallus consisting of short branches with large, short cells, (P) thick-celled, short branches forming crust, (Q) formation of secondary rhizoids; (R) Cladophora globulus; (S, T) Gemmiphora compacta: (S) apressed filaments forming continuous turf, (T) single branched filament. (H, I, K, L, O, Q-T) redrawn from Izhboldina (2007). Scale bars (A-D) $2 \mathrm{~mm}$; (E-G, J) $100 \mu \mathrm{m}$; (H, I, K, L, R) $200 \mu \mathrm{m}$; and (O-Q) $300 \mu \mathrm{m}$. 
DIVERSITY AND PHYLOGENY OF THE CLADOPHORALES OF LAKE BAIKAL

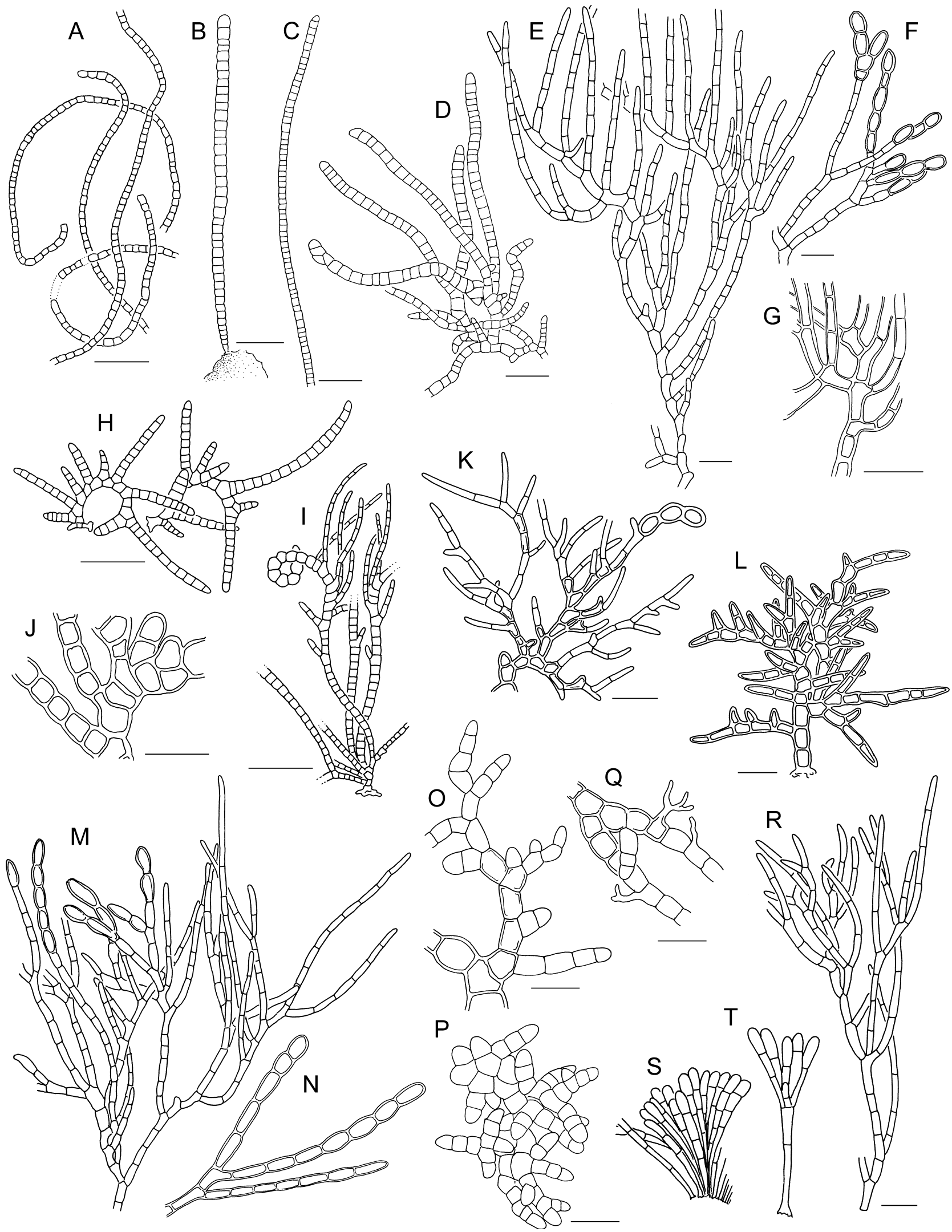


(all specimens are listed in Table S2, details of all analyzed data sets are summarized in Table S3 in the Supporting Information), was assembled for phylogenetic analyses to determine overall relationships using Bayesian Inference (BI; Ronquist and Huelsenbeck 2003). From this preliminary analysis we produced three data sets: data set 1 , a concatenated alignment of LSU and SSU sequences to establish the phylogenetic relationships of the samples from Lake Baikal within the family Cladophoraceae (111 taxa, Pseudorhizoclonium as an outgroup); data set 2, an LSU alignment of 53 Rhizoclonium sequences and 38 sequences of endemic taxa from Lake Baikal (plus 11 freshwater Cladophora sequences as an outgroup) to check for the monophyly of the Baikal clade when more Rhizoclonium lineages are included; and data set 3, a concatenated alignment of LSU, SSU, and ITS sequences of 47 specimens of the Baikal clade (plus Rhizoclonium pachydermum as an outgroup) to investigate the relationships between the endemic taxa.

All three data sets were analyzed using Bayesian Inference (BI) and maximum likelihood (ML). Corrected pair-wise distances were calculated in PAUP* 4.0b10 (Swofford 2002) for the LSU, SSU, and ITS data sets separately. The two concatenated data sets (data set 1 and data set 3) were partitioned into SSU and LSU, and into SSU, ITS, and LSU, respectively, applying unlinked models of nucleotide evolution to each partition, with GTR $+\mathrm{I}+\mathrm{G}$ as the initial model for each partition. BI was performed with MrBayes v3.1.2 (Ronquist and Huelsenbeck 2003) and consisted of two parallel runs of one cold and three incrementally heated chains each, and 10 million generations sampled every 1,000 generations. Posterior probabilities were obtained using a Metropoliscoupled Markov chain Monte Carlo approach. The average standard deviation of the split frequencies of the two parallel runs indicated that the tree samples became increasingly similar and that a stationary distribution was reached. The log files of the runs were also checked with Tracer v1.4.1 (Rambaut and Drummond 2007), and a burn-in sample of 2,500 trees was removed from the 10,000 retained trees before calculating the majority rule consensus trees in MrBayes. ML analyses were performed using RAxML version 8 (Stamatakis 2014) with the GTR + I + G model of nucleotide evolution. The reliability of the ML topologies was evaluated based on 1,000 nonparametric bootstrap replicates (Felsenstein 1985). The trees were visualized with FigTree v.1.2.2. (Rambaut 2008).

\section{RESULTS}

Alignments. Data set 1 had a total length of 2,319 bp (LSU: 611 bp, SSU: 1,708 bp). Data set 2 had a length of 572 bp. Data set 3 had a total length of 3,017 bp (LSU: $569 \mathrm{bp}$, SSU: 1,619 bp, whole ITS region: $829 \mathrm{bp}$, ITS1: $429 \mathrm{bp}, 5.8 \mathrm{~S}$ : $148 \mathrm{bp}$, and ITS2: $252 \mathrm{bp}$ ), the details of all analyzed alignments are summarized in Table S3.

Phylogenetic relationships within the Cladophorales. The Bayesian phylogram resulting from the preliminary data set of 150 sequences of the whole order Cladophorales showed that two species from Lake Baikal, the widespread Aegagropila linnaei and the Baikalian species Cladophora kusnetzowii, grouped with the Pithophoraceae, while all other samples were recovered within the Cladophoraceae (Fig. S2 in the Supporting Information). Cladophora kusnetzowii had identical sequences to A. linnaei (the widespread ITS genotype A; see Boedeker et al. 2010) and should therefore be regarded as a synonym of the latter.

Within the Cladophoraceae, a sample from Lake Baikal identified as the cosmopolitan morphospecies Cladophora glomerata (sample P92; Table S2) grouped with other freshwater taxa from around the world in the Cladophora clade (Fig. 3). Sister to Cladophora is the genus Rhizoclonium, which contained both marine and freshwater Rhizoclonium samples from a range of locations as well as a highly supported clade consisting only of samples from Lake Baikal (bootstrap support 98, posterior probability 1.0; referred to as "the Baikal clade"; Fig. 3). This monophyletic group consists exclusively of the endemic taxa as well as Rhizoclonium samples (samples Q10, Q18, 273, and 628) from Lake Baikal. Even when 53 LSU sequences of Rhizoclonium from around the world were included in the analysis, the Baikal clade was monophyletic within Rhizoclonium (Fig. S3 in the Supporting Information). Relationships within the Baikal clade were basically unresolved based only on LSU and SSU sequences (Fig. 3).

Relationships and molecular diversity within the Baikal clade. When the SSU, LSU, and ITS sequences of the Baikal clade were analyzed together, the resolution of the resulting tree improved significantly, but still many morphospecies and their relationships remained unresolved (Fig. 4). Despite the extraordinary morphological diversity, the level of sequence divergence between lineages in this clade is very low, with only $0.9 \%$ maximum pair-wise differences in the SSU sequences, $1.2 \%$ maximum pair-wise differences in the LSU sequences, and $2.8 \%$ maximum pair-wise differences in the ITS region $(4.0 \%$ in the ITS2 region). In comparison, the maximum pair-wise differences in Rhizoclonium are $8.2 \%$ in the SSU sequences (19 taxa), $8.1 \%$ in the LSU sequences (39 taxa), and at least $9.7 \%$ in the ITS2 region (probably more, as the ITS2 region was aligned by introducing many gaps in order to avoid ambiguously aligned positions, which leads to a very conservative estimate of maximum sequence divergence).

The endemic taxa of the Cladophorales from Lake Baikal are grouped into two main clades (Fig. 4). The well-supported clade A contains the three lineages Cladophora kursanovii, Chaetomorpha moniliformis/Chaetomorpha curta, and C. curta/Rhizoclonium (Fig. 4). Clade B is only poorly supported with $62 \%$ ML bootstrap support and includes eight morphospecies (10 taxa including four varieties).

Clade A comprises mainly unbranched morphologies, only Cladophora kursanovii is (sparsely) branched. Samples from Lake Baikal that were identified as Rhizoclonium sp. were placed in the clade of Baikal endemics rather than with Rhizoclonium lineages from elsewhere in the world (Fig. 3, Fig. S3). These Rhizoclonium specimens are grouped with the attached growth form of Chaetomorpha curta, which is 


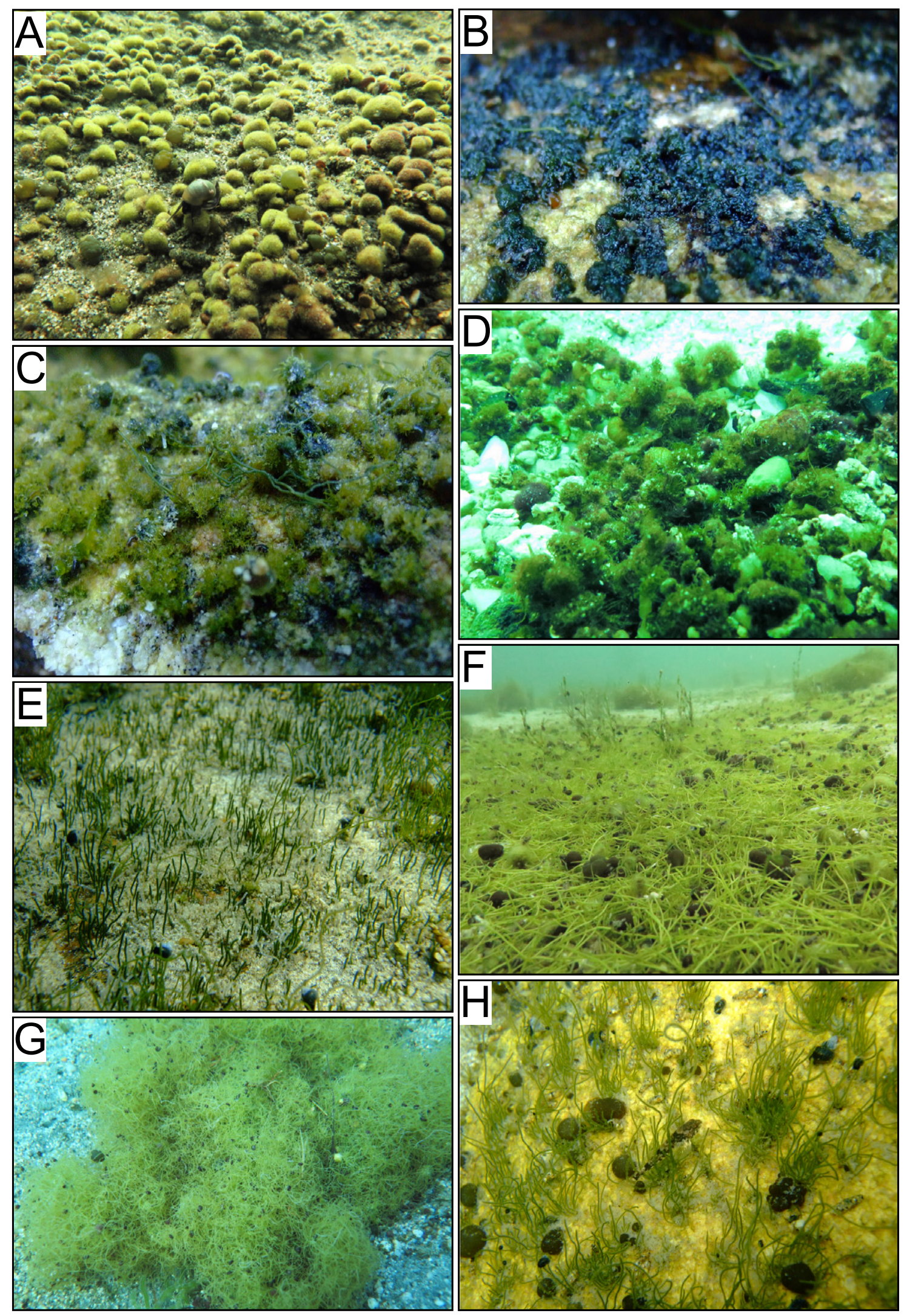

FIG. 2. Underwater photographs of endemic species of the Cladophorales from Lake Baikal, illustrating the morphological diversity. (A) Cladophora compacta, (B) Cladophora kursanovii, (C) Cladophora floccosa (\& Chaetocladiella pumila), (D) Cladophora meyeri, (E) Chaetomorpha moniliformis, (F) Chaetomorpha curta (unattached), (G) Chaetomorpha baicalensis (unattached), and (H) Chaetocladiella pumila. [Color figure can be viewed at wileyonlinelibrary.com] 


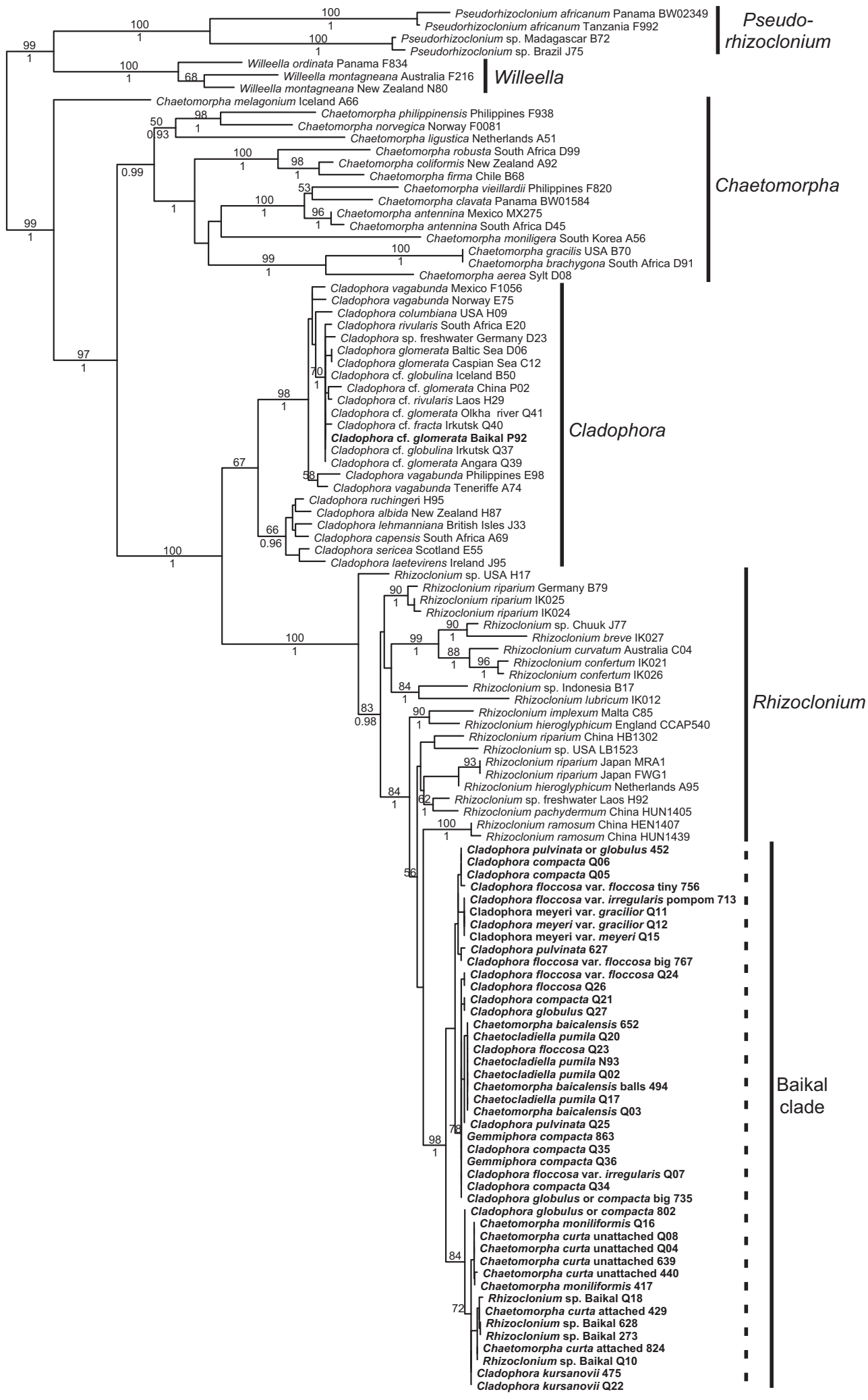

FIG. 3. Bayesian Inference (BI) phylogram inferred from rDNA small-subunit (SSU) and partial large-subunit (LSU) sequences (data set 1) of the Cladophoraceae, including the specimens from Lake Baikal (indicated in bold). Posterior probabilities from BI are indicated below branches, maximum-likelihood bootstrap values are given above the branches. Only bootstrap values above $50 \%$ and posterior probabilities above 0.9 are shown. Pseudocladophoraceae were used as outgroup. The scale bar indicates substitutions per site. 


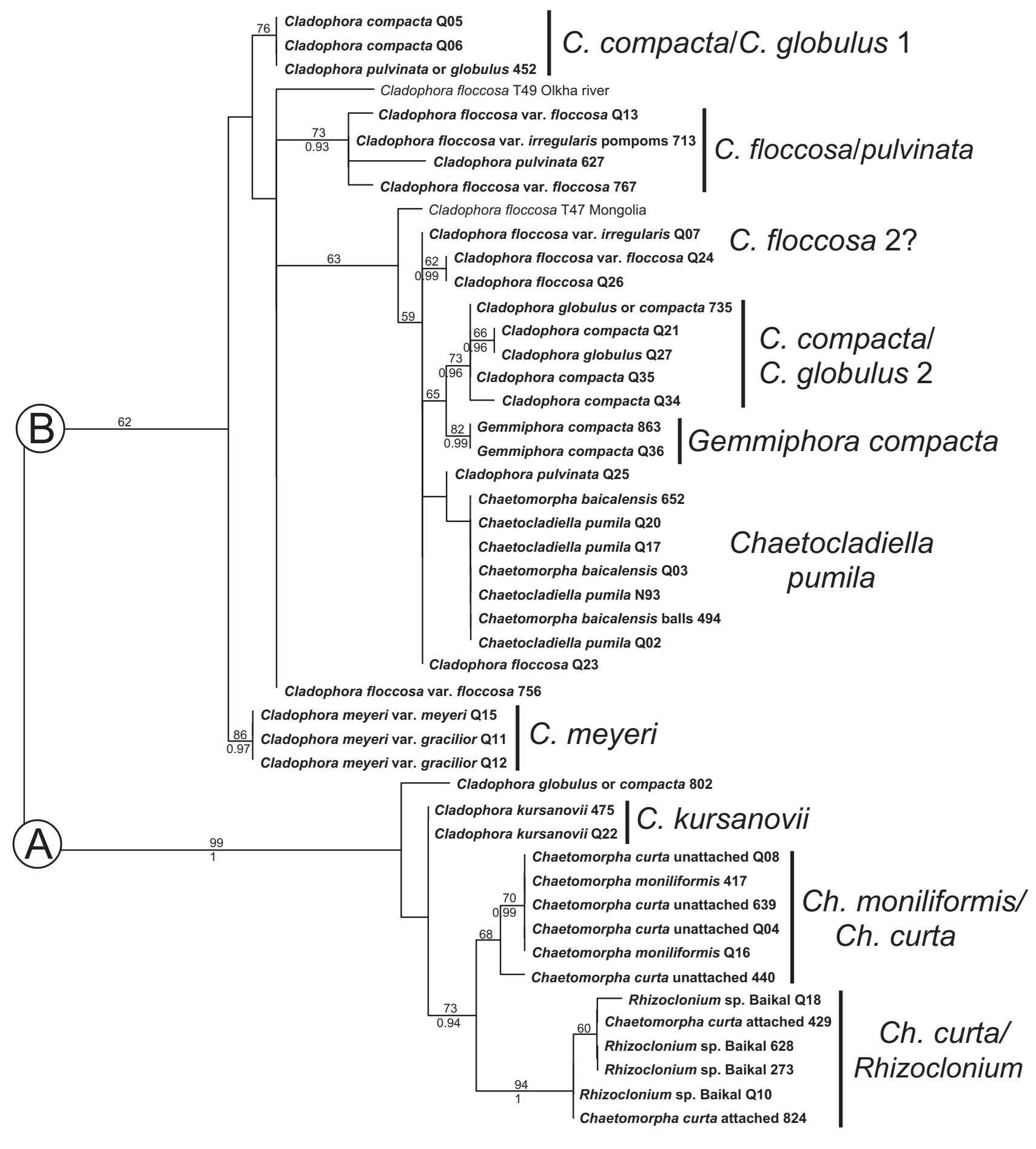

0.005

FIG. 4. Bayesian Inference (BI) phylogram inferred from rDNA small-subunit (SSU) and partial large-subunit (LSU) and internal transcribed spacer (ITS) sequences (data set 3) of the endemic Cladophorales of Baikal (indicated in bold). Posterior probabilities from BI are indicated below branches, maximum-likelihood bootstrap values are given above the branches. Only bootstrap values above $50 \%$ and posterior probabilities above 0.9 are shown. Rhizoclonium pachydermum was used as outgroup (removed for clarity). The scale bar indicates substitutions per site.

genetically distinct from the unattached form of C. curta. The unattached specimens of C. curta are genetically identical to Chaetomorpha moniliformis and appear to be a growth form of this attached species. The LSU sequences of the lineages in clade A differ by only $1 \mathrm{bp}$. 
Clade B is poorly supported and also shows little resolution within the clade. This clade is mainly comprised of densely branched taxa with Cladophoralike morphologies (C. compacta, C. floccosa, C. globulus, C. meyeri, and C. pulvinata), but also contains the unbranched C. baicalensis and the uniquely and very sparsely branched $C$. pumila, as well as the diminutive and sparsely branched $G$. compacta. The varieties of C. meyeri, var. meyeri and var. gracilior, have identical ITS sequences, but the relationships with the other taxa in this clade are not supported. The morphospecies C. compacta is recovered in two distinct clades, however, in both of these clades ("C. compacta/C. globulus 1 \& 2"; Fig. 4) it is grouped together with the smaller and more irregularly branched C. globulus. Cladophora floccosa is also recovered in at least two distinct lineages, and in both lineages the two varieties C. floccosa var. floccosa and var. irregularis are mixed together. However, the relationships are largely unresolved and clades have only moderate support, if any. Within the morphospecies C. floccosa, the ITS sequences between the two lineages differ by $4 \mathrm{bp}$, and the sample from the Olkha river near Irkutsk differs from the other C. floccosa specimens by $6 \mathrm{bp}$. The specimen from Mongolia differs by just $1 \mathrm{bp}$ in the ITS region from the Baikalian samples in the C. floccosa lineage 2.

The morphospecies Cladophora pulvinata, morphologically similar to Cladophora compacta and the smaller Cladophora globulus (mainly differing from C. compacta by not producing very tight, cushion-like hemispherical clusters of thalli), has been tentatively identified three times, however these three specimens differ in their ITS region by at least $3 \mathrm{bp}$ from one another and are grouped with other morphospecies in the phylogenetic tree, or their position is not resolved. The two samples of the monotypic endemic genus Gemmiphora are genetically identical and are sister to the C. compacta/C. globulus 2 clade.

\section{DISCUSSION}

Research on speciation in Lake Baikal and other ancient lakes has focused on animals (Martens 1997, Hausdorf et al. 2003, Macdonald et al. 2005, Yokoyama and Goto 2005, Sherstyankin and Kuimova 2006, Schön and Martens 2012, Karanovic and Sitnikova 2017), while algae have largely been ignored in evolutionary studies, with the exception of diatoms (Mann 1999, Flower 2005, Edlund and Soninkhishig 2009, Kulikovskiy et al. 2012). Our data show that the morphologically and taxonomically diverse endemic Cladophorales of Lake Baikal represent a monophyletic group of closely related taxa nested within the morphologically simple genus Rhizoclonium. These endemic Cladophorales had not been recognized previously as a species flock. Our study established that these taxa fulfill the criteria of a species flock typical for ancient lake radiations: they are endemic, monophyletic, and represent a considerable number of putative species (Greenwood 1984, Schön and Martens 2004).

Monophyly of the endemic Cladophorales is not the only surprise revealed by the molecular data, but the phylogenetic position within the genus $R h i$ zoclonium was also completely unexpected based on morphology. It had been assumed that most of the Baikalian taxa were related to members of the Pithophoraceae (Boedeker et al. 2012), and several of the Cladophora species from Lake Baikal had been previously classified in the genus Aegagropila (C. globulus, C. compacta, C. kursanovii, and C. pulvinata). The morphological diversity expressed by the Baikal endemics is remarkably high for a group of closely related species (see Figs. 1 and 2), and is in stark contrast to the narrow morphological range encountered in the genetically diverse genus Rhizoclonium, in which the Baikal clade is nested. In Rhizoclonium, morphological differentiation has not accompanied molecular differentiation during the evolution of species, and the lineages are characterized by very broad ecological tolerances (Leliaert and Boedeker 2007, Boedeker et al. 2016, Skaloud et al. 2018). It should be mentioned that the placement of the branched species $R$. pachydermum in Rhizoclonium has been confirmed by molecular data (Zhao et al. 2014), and another branched species, Rhizoclonium ramosum, has since been described from China (Zhao et al. 2016). These two taxa show morphological similarities to C. floccosa, but did not group with the Baikal samples in our phylogenies (Fig. 2, Fig. S3). In many aspects the Baikal clade appears to be the exact opposite of Rhizoclonium, i.e., low interspecific genetic divergence but exceptional morphological diversity and occurring in a habitat with very particular and stable environmental conditions (hyperoligotrophic, cold).

The grouping of the Baikal clade within Rhizoclonium represents a difficult taxonomic and nomenclatorial situation. While paraphyly is a natural stage early in the speciation process (Hudson and Coyne 2002, Rosenberg 2003), the taxonomic treatment of genera is a different issue. If paraphyletic genera were not to be recognized, either all the endemic taxa from Lake Baikal would become Rhizoclonium or the genus Rhizoclonium would be split into at least nine genera, most of which would lack any morphologically discerning characters. The latter option is further confounded by the lack of sequence data for any of the numerous type species which would make assigning the generic name problematic (see Boedeker et al. 2016, Škaloud et al. 2018). Either way, the fascinating taxa endemic to Lake Baikal need to be better understood and should be studied in more detail before any taxonomic changes are considered.

Phylogenetic data support only some of the Baikal morphospecies (Cladophora compacta, Cladophora meyeri, and Cladophora moniliformis). For several other morphospecies no assessment can be made due to 
the lack of resolution in the phylogenetic trees. This lack of resolution stems from the small amount of divergence in the data set even in ITS sequences (max. 2.8\%), which typically have a strong phylogenetic signal at the interspecific level in the Cladophorales with, for example, sister species originating from polyploid speciation differing by $14 \%$ in Wittrockiella (Boedeker et al. 2017) and 7\%-29\% between species divergence in Boodlea and Phyllodictyon (Leliaert et al. 2008, 2009b). While most of the morphospecies are well defined and easily identified, there is also a problem with identifying some of the morphospecies due to ambiguities in morphological character states (namely, C. compacta, C. globulus, and C. pulvinata; see Table S1), therefore the names used in Table S2 and in Figure 4 must be treated with some caution. These three species all produce hemispherical thalli and have been placed in the Cladophora section Pulvinata (Skabichevsky 1976), which is morphologically similar to the distantly related genus Aegagropila. The small thalli of C. globulus might actually represent juvenile stages of different larger morphospecies such as C. compacta or C. pulvinata, as noted by Hollerbach and Sdobnikova (1980). Our molecular data indicate that two unattached morphospecies are growth forms of attached species: the unattached C. curta (Fig. 2F) appears to be conspecific with C. moniliformis (Figs. 1B and 2E), and the unattached C. baicalensis (Figs. 1A and 2G) appears to be conspecific with C. pumila (Figs. 1D and 2H). Furthermore, attached C. curta specimens had ITS sequences identical to unattached, entangled specimens with a Rhizoclonium-like morphology. Our data furthermore indicate also some level of cryptic diversity, for example, the morphospecies C. compacta and C. floccosa are both recovered in more than one moderately supported lineage. However, several of the endemic taxa from Lake Baikal seem to show little phenotypic plasticity, as during sample collection for this study up to five morphospecies were encountered on a single rock, without any intermediate growth forms present.

While the clade containing the unique taxa from Lake Baikal is referred to by us as the Baikal endemics, it should be noted that two samples in this clade were from outside Lake Baikal, one sample of Cladophora floccosa was collected from the Olkha river near Irkutsk ( $\sim 60 \mathrm{~km}$ west of Lake Baikal) and another sample of C. floccosa was collected from a mountain lake in Mongolia (Lake Davaa, Khangai mountains, 2,465 m above sea level), $\sim 550 \mathrm{~km}$ southwest of Lake Baikal. Cladophora floccosa and C. miscroscopica (as C. solitaria) have also been reported from Lake Hövsgöl (Khovsgol nuur/Khubsugul) in Mongolia, an ancient lake $\sim 200 \mathrm{~km}$ southwest of Lake Baikal (Zagorenko and Izhboldina 1976, 1983, Kozhova et al. 1994), but no molecular data are available. The species Cladophora kozhowii described from Lake Khovsgol is morphologically similar to the Baikalian C. meyeri (Zagorenko and Izhboldina 1977). Several scenarios to explain these findings can be considered: (i) the species originated in Lake Baikal and subsequently some dispersed to lakes in Mongolia, (ii) the Baikalian species flock originated allopatrically in ancestral mountain lakes of southern Siberia and species survived in Lake Baikal and a few species also in other lakes in the region, or (iii) at least some of the species evolved in allopatry and come into secondary contact in Lake Baikal. The second and third scenario seem unlikely considering the very low divergence in ITS sequences (the Mongolian C. floccosa differs by just $1 \mathrm{bp}$ in the ITS region from Lake Baikal), which suggests that this species flock diversified relatively recently during the late Pleistocene and which is typical for recent explosive radiations (Kontula et al. 2003, Kaygorodova et al. 2007, Ford et al. 2015, Winkler et al. 2015). It should be noted though that the ITS diversity and the distribution of taxa in southern Siberia might be underestimated due to lack of extensive sampling in the region. More data will be useful before rejecting scenarios involving allopatric speciation in the mountainous region of southern Siberia.

Comparisons to rates of nucleotide substitution in other groups, to estimate the time since the most recent common ancestor, might be somewhat confounded since the endemic Cladophorales from Lake Baikal live in a unique environment which is characterized by very low nutrient levels and very low temperatures (Kozhova and Izmest'eva 1998) and thus very low metabolic rates. These perennial species experience $\sim 6$ months of reduced irradiance under the ice every year and individuals are thought to be long lived, factors that could influence mutation rates. To resolve the evolutionary relationships in this group more variable markers such as microsatellites or SNPs are required. Still, with the data available it appears that this group radiated in relatively recent times in Lake Baikal. Despite the great age of Lake Baikal, many of the radiations in other taxonomic groups have also occurred relatively recently (Hausdorf et al. 2003, Kontula et al. 2003, Yokoyama and Goto 2005, Kaygorodova et al. 2007, Schön and Martens 2012, Stelbrink et al. 2015, Karanovic and Sitnikova 2017). During the last $5 \mathrm{My}$, the lake passed through several climate changes, from a subtropical ( $\sim 5 \mathrm{Mya})$, a transitional stage (from $\sim 2.6$ to $2.4 \mathrm{Mya}$ ), to the current coldtemperate climate (Sherstyankin and Kuimova 2006). Although the origin of the species and the timing of their radiation has not been investigated in all groups, it has been suggested that the cooling of the lake during the Pleistocene ( $\sim 2$ Mya) produced many of the species assemblages that are present to date (Sherbakov 1999, Mats et al. 2011).

Radiations of organisms originate by several different evolutionary processes, typically linked to new opportunity provided by drastic ecological change 
resulting in new environments and reduced competition, such as ecological speciation along environmental gradients, polyploidy, hybridization, and combinations of these phenomena (Kozhova and Izmest'eva 1998, Barrier et al. 1999, Schön and Martens 2004, Paun et al. 2006, Herder et al. 2008, Yoder et al. 2010). While behavior and sexual selection are important factors in animal radiations (Higashi et al. 1999, Seehausen 2006, Herder et al. 2008, Gonzalez-Voyer and Kolm 2011), they are irrelevant in algae. Thus, further studies in this algal system are not only likely to provide an additional example of sympatric speciation and rapid radiation but also to reveal novel patterns and processes involved in these evolutionary processes. One such novel feature is the role of polyploidy. Although chromosome numbers have not yet been studied in the Lake Baikal species, chromosome numbers of $12,24,36,48,72$, and 96 have been reported for the freshwater Cladophora clade (e.g., Godward 1959, Wik-Sjöstedt 1970, Kapraun 2007), indicating that polyploidy may be common in the Cladophorales. Polyploidy is also associated with environmental change and can result in novel ecological optima and the occupation of novel niches (Paun et al. 2006, Fawcett et al. 2009, Parisod et al. 2010). It is difficult to imagine that the morphological diversity in the Baikal clade is adaptive, and might instead be a result of polyploidy (either allopolyploid or autopolyploid). Changes in ploidy levels are frequently associated with changes in morphology (Comai 2005, Rieseberg and Willis 2007) as is seen in many plant cultivars such as bread wheat, kiwifruit, or strawberries, but this has also been established for green algae (e.g., McCourt and Hoshaw 1990). It would be therefore interesting to investigate if polyploidy is responsible for the diversity in the Baikal clade.

\section{CONCLUSIONS}

Molecular data show that the endemic species of Cladophorales from the Baikalian region are a monophyletic group nested within the genus Rhizoclonium, despite their morphological affinities with other genera. This species flock of very closely related taxa most likely radiated relatively recently, based on the very low sequence divergence in ITS rDNA sequences. Most likely these taxa evolved from a common ancestor in Lake Baikal. The large morphological diversity in this clade combined with the lack of considerable genetic divergence makes polyploid speciation a likely process involved in the radiation of these taxa. The endemic Cladophorales of Lake Baikal represent a promising candidate system to study speciation in sympatry.

Many people helped with making this study possible and we acknowledge A. Kupchinsky, H. Anlauf, and S. Ihnken for assistance with SCUBA diving, sample collection, and underwater photography; the crews of the research vessels Titov, Papanin, and Koptyug for making the expeditions around Lake Baikal possible; L. A. Izhboldina for imparting her knowledge and detailed information on morphology and distribution of the algae of Lake Baikal, which greatly helped with successful sampling; and D. Matafonov and E. Volkova for assistance with specimens. CB acknowledges the German Academic Exchange Service (DAAD) and the Royal Society of New Zealand (Marsden Fund) for postdoctoral scholarships, the Linnean Society for a Systematics Research Fund (SRF), and the Royal Netherlands Academy of Arts and Sciences (KNAW) for a Schuure-Beijerinck-Popping fund. Investigations were partly supported by federal project no. 0345-2016-0009 "Large-scale changes in ecology and biodiversity of coastal zone communities of Lake Baikal: interdisciplinary research, reasoning and prognosis" to O.A. Timoshkin. All authors declare that there is no conflict of interest.

Albrecht, C. \& Wilke, T. 2008. Ancient Lake Ohrid: biodiversity and evolution. Hydrobiologia 615:103-40.

Barrier, M., Baldwin, B. G., Robichaux, R. H. \& Purugganan, M. D. 1999. Interspecific hybrid ancestry of a plant adaptive radiation: allopolyploidy of the Hawaiian silversword alliance (Asteraceae) inferred from floral homeotic gene duplications. Mol. Biol. Evol. 16:1105-13.

Boedeker, C., Eggert, A., Immers, A. \& Wakana, I. 2010. Biogeography of Aegagropila linnaei (Cladophorophyceae, Chlorophyta): a widespread freshwater alga with low effective dispersal potential shows a glacial imprint in its distribution. J. Biogeogr. 37:1491-503.

Boedeker, C., Leliaert, F. \& Zuccarello, G. C. 2016. Molecular phylogeny of the Cladophoraceae (Cladophorales, Ulvophyceae), with the resurrection of Acrocladus Nägeli and Willeella Børgesen, and the description of Lurbica gen. nov. and Pseudorhizoclonium gen. nov. J. Phycol. 52:905-28.

Boedeker, C., O'Kelly, C. J., Star, W. \& Leliaert, F. 2012. Molecular phylogeny and taxonomy of the Aegagropila clade (Cladophorales, Chlorophyta), including the description of Aegagropilopsis gen. nov. and Pseudocladophora gen. nov. J. Phycol. 48:808-25.

Boedeker, C., O'Kelly, C., West, J. A., Hanyuda, T., Neale, A., Wakana, I., Wilcox, M. D., Karsten, U. \& Zuccarello, G. C. 2017. Molecular phylogeny and taxonomic revision of the genus Wittrockiella (Pithophoraceae, Cladophorales), including the descriptions of W. australis sp. nov. and W. zosterae sp. nov. J. Phycol. 52:522-40.

Bourrelly, P. 1966. Les Algues D'eau Douce. I Les Algues Vertes. Éditions N. Boubée \& Cie, Paris, France, 511 pp.

Comai, L. 2005. The advantages and disadvantages of being polyploid. Nat. Rev. Genet. 6:836-46.

Edgar, R. C. 2004. MUSCLE: multiple sequence alignment with high accuracy and high throughput. Nucl. Acids Res. 32:17927.

Edlund, M. B. \& Soninkhishig, N. 2009. The Navicula reinhardtii species flock (Bacillariophyceae) in ancient Lake Hövsgöl, Mongolia: description of four taxa. Nova Hedwig. Beih. 135:239-56.

Fawcett, J. A., Maere, S. \& Van de Peer, Y. 2009. Plants with double genomes might have had a better chance to survive the Cretaceous-Tertiary extinction event. Proc. Natl. Acad. Sci. USA 106:5737-42.

Felsenstein, J. 1985. Confidence limits on phylogenies: an approach using the bootstrap. Evolution 39:783-91.

Flower, R. J. 2005. A review of diversification trends in diatom research with special reference to taxonomy and environmental applications using examples from Lake Baikal and elsewhere. Proc. Calif. Acad. Sci. 56:107-28.

Ford, A. G. P., Dasmahapatra, K. K., Rüber, L., Gharbi, K., Cezard, T. \& Day, J. J. 2015. High levels of interspecific gene 
flow in an endemic cichlid fish adaptive radiation from an extreme lake environment. Mol. Ecol. 24:3421-40.

Genner, M. J. \& Turner, G. F. 2011. Ancient hybridization and phenotypic novelty within Lake Malawi's cichlid fish radiation. Mol. Biol. Evol. 29:195-206.

Glaubrecht, M. \& von Rintelen, T. 2008. The species flocks of lacustrine gastropods: the Sulawesi lakes as model system in speciation and adaptive radiation. Hydrobiologia 615:181-99.

Godward, M. B. E. 1959. Chromosome numbers in the algae II Chlorophyta. Eur. J. Phycol. 1:43-6.

Goff, L. \& Moon, D. 1993. PCR amplification of nuclear and plastid genes from algal herbarium specimens and algal spores. J. Phycol. 29:381-4.

Gonzalez-Voyer, A. \& Kolm, N. 2011. Rates of phenotypic evolution of ecological characters and sexual traits during the Tanganyikan cichlid adaptive radiation. J. Evol. Biol. 24:237888.

Greenwood, P. H. 1984. What is a species flock? In Echelle, A. A. \& Kornfield, I. [Eds.] Evolution of Fish Species Flocks. University of Maine, Orono Press, Orono, ME, pp. 13-9.

Hanyuda, T., Wakana, I., Arai, S., Miyaji, K., Watano, Y. \& Ueda, K. 2002. Phylogenetic relationships within Cladophorales (Ulvophyceae, Chlorophyta) inferred from 18S rRNA gene sequences, with special reference to Aegagropila linnaei. J. Phycol. 38:564-71.

Hassouna, N., Michot, B. \& Bachellerie, J. P. 1984. The complete nucleotide sequence of mouse $28 \mathrm{~S}$ rRNA gene. Implications for the process of size increase of the large subunit rRNA in higher eukaryotes. Nucleic Acids Res. 12:3563-83.

Hausdorf, B., Röpstorf, P. \& Riedel, F. 2003. Relationships and origins of endemic Lake Baikal gastropods (Caenogastropoda: Rissooidea) based on mitochondrial DNA sequences. Mol. Phylogenet. Evol. 26:435-43.

Hayakawa, Y. I., Ogawa, T., Yoshikawa, S., Ohki, K. \& Kamiya, M. 2012. Genetic and ecophysiological diversity of Cladophora (Cladophorales, Ulvophyceae) in various salinity regimes. Phycol. Res. 60:86-97.

Herder, F., Pfaender, J. \& Schliewen, U. K. 2008. Adaptive sympatric speciation of polychromatic "roundfin" sailfin silverside fish in lake Matano (Sulawesi). Evolution 62:2178-95.

Higashi, M., Takimoto, G. \& Yamamura, N. 1999. Sympatric speciation by sexual selection. Nature 402:523-6.

Hollerbach, M. M. \& Sdobnikova, N. V. 1980. Green algae: Siphonocladales. In Vinogradova, K. L., Gollerbach, M. M., Zauer, L. M. \& Sdobnikova, N. V. [Eds.] Guide to Freshwater Algae of the USSR, Vol. 13. Nauka-Center, St Petersburg (Leningrad), pp. 7-89.

Hou, Z., Sket, B., Fišer, C. \& Li, S. 2011. Eocene habitat shift from saline to freshwater promoted Tethyan amphipod diversification. Proc. Natl. Acad. Sci. USA 108:14533-8.

Hudson, R. R. \& Coyne, J. A. 2002. Mathematical consequences of the genealogical species concept. Evolution 56:1557-65.

Izhboldina, L. A. 2007. Guide and key to benthonic and periphyton algae of Lake Baikal (meio- and macrophytes) with short notes of their ecology. Nauka-Center, Novosibirsk, 248 pp.

Kapraun, D. F. 2007. Nuclear DNA content estimates in green algal lineages: Chlorophyta and Streptophyta. Ann. Bot. 99:677-701.

Karanovic, I. \& Sitnikova, T. Y. 2017. Phylogenetic position and age of Lake Baikal candonids (Crustacea, Ostracoda) inferred from multigene sequence analyzes and molecular dating. Ecol. Evol. 7:7091-103.

Kaygorodova, I. A., Sherbakov, D. Y. \& Martin, P. 2007. Molecular phylogeny of Baikalian Lumbriculidae (Oligochaeta): evidence for recent explosive speciation. Comp. Cytogenet. 1:7184.

Kontula, T., Kirilchik, S. V. \& Väinöl, R. 2003. Endemic diversification of the monophyletic cottoid fish species flock in lake Baikal explored with mt DNA sequencing. Mol. Phylogenet. Evol. 27:143-55.

Kozhov, M. M. 1963. Lake Baikal and its Life. Springer Netherlands, Dordrecht, 344 pp.
Khozhova, O. M. \& Izmest'eva, L. R. 1998. Lake Baikal. Evolution and Biodiversity. Backhuys Publ, Leiden, $447 \mathrm{pp}$

Khozhova, O. M., Izmest'eva, L. R. \& Erbaeva, E. A. 1994. A review of the hydrobiology of Lake Khubsugul (Mongolia). Hydrobiologia 291:11-9.

Kulikovskiy, M. S., Lange-Bertalot, H., Metzeltin, D. \& Witkowski, A. 2012. Lake Baikal: hotspot of endemic diatoms I. Iconogr. Diatomol. 23:1-608.

Leliaert, F. \& Boedeker, C. 2007. Cladophorales. In Brodie, J., Maggs, C. A. \& John, D. [Eds.] Green Seaweeds of Britain and Ireland. Natural History Museum Publications, London, UK, pp. 131-83.

Leliaert, F., De Clerck, O., Verbruggen, H., Boedeker, C. \& Coppejans, E. 2007. Molecular phylogeny of the Siphonocladales (Chlorophyta: Cladophorophyceae). Mol. Phylogenet. Evol. 44:1237-56.

Leliaert, F., Rousseau, F., de Reviers, B. \& Coppejans, E. 2003. Phylogeny of the Cladophorophyceae (Chlorophyta) inferred from partial LSU rRNA gene sequences: is the recognition of a separate order Siphonocladales justified? Eur. J. Phycol. 38:233-46.

Leliaert, F., Rueness, J., Boedeker, C., Maggs, C. A., Cocquyt, E., Verbruggen, H. \& De Clerck, O. 2009a. Systematics of the marine microfilamentous green algae Uronema curvatum and Urospora microscopica (Chlorophyta). Eur. J. Phycol. 44:487-96.

Leliaert, F., Verbruggen, H., Wysor, B. \& De Clerck, O. 2009b. DNA taxonomy in morphologically plastic taxa: algorithmic species delimitation in the Boodlea complex (Chlorophyta: Cladophorales). Mol. Phylogenet. Evol. 53:122-33.

Leliaert, F., Wysor, B., Verbruggen, H., Vlaeminck, C. \& De Clerck, O. 2008. Phyllodictyon robustum (Setchell et Gardner) comb. nov. (Siphonocladales, Chlorophyta), a morphologically variable species from the tropical Pacific coast of America. Cryptogamie Algol. 29:217-33.

Macdonald, K. S. III, Yampolsky, L. \& Duffy, E. 2005. Molecular and morphological evolution of the amphipod radiation of Lake Baikal. Mol. Phylogenet. Evol. 35:323-43.

Mann, D. G. 1999. The species concept in diatoms. Phycologia 38:437-95.

Martens, K. 1997. Speciation in ancient lakes. Trends Ecol. Evol. $12: 177-82$.

Mats, V. D. 1993. The structure and development of the Baikal rift depression. Earth Sci. Rev. 34:81-118.

Mats, V. D., Shcherbakov, D. Y. \& Efimova, I. M. 2011. Late Cretaceous-Cenozoic history of the Lake Baikal depression and formation of its unique biodiversity. Stratigr. Geol. Correl. 19:404-23.

Mazepova, G. F. 1990. Ostracod Crustaceans of Lake Baikal. Nauka Center, Novosibirsk, 472 pp.

McCourt, R. M. \& Hoshaw, R. W. 1990. Noncorrespondence of breeding groups. Orphology, and monophyletic groups in Spirogyra (Zygnemataceae: Chlorophyta) and the application of the species concept. Syst. Bot. 15:69-78.

Meyer, C. 1922. Quelques recherches scientifiques sur la flore des algues du lac Baikal. J. Sect. Moscou Soc. Bot. Russ. 1:1-27 (in Russian).

Meyer, C. J. 1925. Sur l'endémisme de la flore algologique du Lac Baikal. Rev. Algol. 2:241-57.

Meyer, C. J. 1926. Untersuchung über die Algenflora des Baikalsees. Ber. Deut. Bot. Ges. 44:410-9.

Meyer, C. J. 1927. Les algues de l'extrémité septentrionale du lac Baikal. Arch. Russ. Protistol. 6:93-118.

Meyer, C. J. [K. I.] 1930a. Einige neue Algenformen des Baikalsees. Arch. Protistenk. 72:158-75.

Meyer, C. J. 1930b. Einführung in die Algenflora des Baikalsees. Bull. Soc. Nat. Moscou Sect. Biol. Nouvelle Serie 39:170-346.

Meyer, C. I. \& Skabichevsky, A. P. 1965. Genus novum Cladophoracearum. Novosti Sistematiki Nizshikh Rastenii 2:41-4.

Parisod, C., Holderegger, R. \& Brochmann, C. 2010. Evolutionary consequences of autopolyploidy. New Phytol. 186:5-17.

Paun, O., Stuessy, T. F. \& Hörandl, E. 2006. The role of hybridization, polyploidization and glaciation in the origin 
and evolution of the apomictic Ranunculus cassubicus complex. New Phytol. 171:223-36.

Rambaut, A. 2007. Se-Al (multiple sequence alignment program), v2.Oa11. Available at: http://tree. bio.ed.ac.uk/software/sea (last accessed 24 June 2016).

Rambaut, A. 2008. FigTree v.1.1.2. Available at: http://tree.bio.e d.ac.uk/software/figtree/ (last accessed 24 June 2016).

Rambaut, A. \& Drummond, A. J. 2007. Tracer v1.4. Available at: http://tree.bio.ed.ac.uk/software/tracer (last accessed 24 June 2016).

Rieseberg, L. H. \& Willis, J. H. 2007. Plant speciation. Science 317:910-4.

Ronquist, F. \& Huelsenbeck, J. P. 2003. MRBAYES 3: Bayesian phylogenetic inference under mixed models. Bioinformatics 19:1572-4.

Rosenberg, N. A. 2003. The shapes of neutral gene genealogies in two species: probabilities of monophyly, paraphyly, and polyphyly in a coalescent model. Evolution 57:1465-77.

Rossiter, A. \& Kawanabe, H. 2000. Ancient Lakes: Biodiversity, Ecology and Evolution. Advances in Ecological Research (Vol. 31). Academic Press, San Diego, California, 624 pp.

Schön, I. \& Martens, K. 2004. Adaptive, pre-adaptive and nonadaptive components of radiations in ancient lakes: a review. Org. Divers. Evol. 4:137-56.

Schön, I. \& Martens, K. 2012. Molecular analyses of ostracod flocks from Lake Baikal and Lake Tanganyika. Hydrobiologia 682:91-110.

Seehausen, O. 2006. African cichlid fish: a model system in adaptive radiation research. Proc. R. Soc. B Biol. Sci. 273:1987-98.

Semernoy, V. P. 2004. Oligochaeta of Lake Baikal. Nauka Center, Novosibirsk, 528 pp.

Sherbakov, D. Y. 1999. Molecular phylogenetic studies on the origin of biodiversity in Lake Baikal. Trends Ecol. Evol. 14:92-5.

Sherstyankin, P. P. \& Kuimova, L. N. 2006. Hydrophysical processes in Lake Baikal in its transition from subtropical to modern climates. Hydrobiologia 568:253-7.

Shirokaya, A. A., Sitnikova, T. Y., Kijashko, P. V., Shydlovskyy, I. V., Prozorova, L. A. \& Yamamuro, M. 2017. A review of the Lake Baikal limpets, family Acroloxidae Thiele, 1931 (Mollusca: Pulmonata: Hygrophila), based on type specimens, with keys to the genera. Arch. Molluskenkd. 146:964.

Skabichevsky, A. P. 1931. Sur les nouvelles espèces et les nouveaux genres des algues vertes du lac Baikal. Bull. Inst. Sci. Biol. Geogr. Univ. Irkoutsk 5:69-77 (in Russian).

Skabichevsky, A. P. 1936. Einige Anmerkungen über die algologie des Baikalsees I. Uber einige Vertreter der Familie Cladophoraceae. Bull. Inst. Sci. Biol. Geogr. Univ. Irkoutsk 7:32-41 (in Russian).

Skabichevsky, A. P. 1965. Nonnulae Cladophoraceae e lacu Baical. Novosti sistematiki nizshikh rastenii $2: 44-50$.

Skabichevsky, A. P. 1968. De nomine generis Cladochaete C. Meyer et Skabitsch. in nomen Chaetocladiella C. Meyer et Skabitsch. nomen nov. mutato. Novosti sistematiki nizshikh rastenii 5:73-4 (in Russian).

Skabichevsky, A. P. 1969. Species nova generis Chaetomorpha Kütz. Novosti sistematiki nizshikh rastenii 6:47-52.

Skabichevsky, A. P. 1970. Ad morphologiam Chaetocladiella pumila (C. Meyer) C. Meyer et Skabitsch. (Chlorophyceae, Cladophoraceae). Novosti sistematiki nizshikh rastenii 7:27-32 (in Russian).

Skabichevsky, A. P. 1976. The Cladophoraceae in the flora of Lake Baikal. Byulleten Moskovskogo Obshchestva Ispytatelei Prirody, Otdel Biologicheskii 81:139-43.

Škaloud, P., Rindi, F., Boedeker, C. \& Leliaert, F. 2018. Freshwater Flora of Central Europe, Vol 13: Chlorophyta: Ulvophyceae. Springer Spektrum, Berlin, Heidelberg, 283 pp.

Stamatakis, A. 2014. RAxML Version 8: a tool for phylogenetic analysis and post-analysis of large phylogenies. Bioinformatics 30:1312-3.

Stelbrink, B., Shirokaya, A. A., Clewing, C., Sitnikova, T. Y., Prozorova, L. A. \& Albrecht, C. 2015. Conquest of the deep, old and cold: an exceptional limpet radiation in Lake Baikal. Biol Letters. 11:20150321.

Swofford, D. L. 2002. PAUP*. Phylogenetic Analysis Using Parsimony (*and Other Methods), Version 4. Sinauer Associates, Sunderland, Massachusetts.

Timoshkin, O. A. 1999. Biology of Lake Baikal: 'White spots' and progress in research. Berliner Geowiss. Abh. 30:333-48.

Timoshkin, O. A. 2001-2011. Index of Animal Species Inhabiting Lake Baikal and its Catchment Area. In 2 Volumes and 4 books. Nauka Publ., Novosibirsk, Vol. 1, book 1 (2001): 832 p.; Vol. 1, book 2 (2004): 833-1679 p.; Vol. 2, book 1 (2009): 980 p.; Vol. 2, book 2 (2010-2011): 981-1668 p.

Timoshkin, O. A., Sitnikova, T. Y., Rusinek, O. T., Pronin, N. M., Proviz, V. I., Mel'nik, N. G. \& Kamaltynov, R. M. 2004. Index of Animal Species Inhabiting Lake Baikal and Its Catchment Area. Vol. I: Lake Baikal, Book 2. Nauka-Center, Novosibirsk, pp. 981-1679.

White, T. J., Bruns, T., Lee, S. \& Taylor, J. 1990. Amplification and direct sequencing of fungal ribosomal genes for phylogenetics PCR protocols. In Innis, M. A., Gelfand, D. H., Sninsky, J. J. \& White, T. J. [Eds.] A Guide to Molecular Methods and Applications. Academic Press, New York, pp. $315-22$.

Wiens, M., Wrede, P., Grebenjuk, V. A., Kaluzhnaya, O. V., Belikov, S. I., Schröder, H. C. \& Müller, W. E. 2009. Towards a molecular systematics of the Lake Baikal/Lake Tuva sponges. Prog. Mol. Subcell. Biol. 47:111-44.

Wik-Sjöstedt, A. 1970. Cytogenetic investigations in Cladophora. Hereditas 66:233-62.

Winkler, I. A., Blasche, J. D., Davis, D. J., Stireman, J. O. III, O’Hara, J. E., Ceretti, P. \& Moulton, J. K. 2015. Explosive radiation or uninformative genes? Origin and early diversification of tachinid flies (Diptera: Tachinidae). Mol. Phylogenet. Evol. 88:38-54.

Yoder, J. B., Clancey, E., Des Roches, S., Eastman, J. M., Gentry, L., Godsoe, W., Hagey, T. J. et al. 2010. Ecological opportunity and the origin of adaptive radiations. J. Evol. Biol. 23:1581-96.

Yokoyama, R. \& Goto, A. 2005. Evolutionary history of freshwater sculpins, genus Cottus (Teleostei; Cottidae) and related taxa, as inferred from mitochondrial DNA phylogeny. Mol. Phylogenet. Evol. 36:654-68.

Zagorenko, G. F. \& Izhboldina, L. A. 1976. An occurrence of the endemic Baikalian Cladophora in Lake Hövsgöl (MPR). In Kozhova, O. M. [Ed.] New Data on Fauna and Flora of Lake Baikal. Irkutsk State University, Irkutsk, pp. 49-58.

Zagorenko, G. F. \& Izhboldina, L. A. 1977. Species nova generis Cladophora Kütz. Novosti sistematiki nizshikh rastenii 14:20-4.

Zagorenko, G. F. \& Izhboldina, L. A. 1983. De positione systematics et distributione Chaetomorphae solitariae Skabitsch. (Chlorophyta). Novosti sistematiki nizshikh rastenii 20:18-22.

Zhao, Z. J., Zhu, H., Hu, Z. Y. \& Liu, G. X. 2014. Occurrence of true branches in Rhizoclonium (Cladophorales, Ulvophyceae) and the reinstatement of Rhizoclonium pachydermum Kjellman. Phytotaxa 166:273-84.

Zhao, Z. J., Zhu, H., Liu, G. X. \& Hu, Z. Y. 2016. Rhizoclonium ramosum sp. nov. (Cladophorales, Chlorophyta), a new freshwater algal species from China. Fottea 16:12-21.

\section{Supporting Information}

Additional Supporting Information may be found in the online version of this article at the publisher's web site:

Figure S1. Sampling locations around Lake Baikal. 
Figure S2. Bayesian inference phylogram of the order Cladophorales based on rDNA SSU and partial LSU sequences.

Figure S3. Bayesian inference phylogram of the genus Rhizoclonium, including the specimens from Lake Baikal based on rDNA partial LSU sequences.

Table S1. Overview of the species of Cladophorales endemic to Lake Baikal with information on synonyms, morphology, and distributions.

Table S2. Information on Cladophorales specimens used in the phylogenetic analyses, with sample and voucher numbers as well as GenBank accession numbers of the SSU, SSU and ITS rDNA sequences.

Table S3. Details of DNA sequence alignments. 